\title{
Cytotoxicity of two epoxy resin based root canal sealers using the ${ }^{51} \mathrm{Cr}$-release method
}

\begin{abstract}
The cytotoxicity of fresh samples of AH26 and $\mathrm{AH}$ Plus were tested using the ${ }^{51} \mathrm{Cr}$ release method at 12 and $72 \mathrm{~h}$. Heteroploid L929 mouse fibroblasts were used as target cells. For the ${ }^{51} \mathrm{Cr}$-release assay, cells were labeled with ${ }^{51} \mathrm{Cr}$ before exposure to the test materials, and the radioactivity in the supernatant was counted with a gamma particle counter. The difference in cytotoxicity between the two materials was evaluated using the Wilcoxon Sum-Rank Test. The difference between AH26 and AH Plus was not statistically significant at $12 \mathrm{~h}(\mathrm{p}=0.8345)$ and at $72 \mathrm{~h}(\mathrm{p}=0.676)$. Both AH26 and AH Plus had gamma particle readings that were significantly lower than the positive control (formocresol) and significantly higher than the negative control (labeled, but material free cell suspension), as assessed by Wilcoxon Sum-Rank Tests.
\end{abstract}

Volume I Issue 4 - 2014

Omer Gorduysus M, Melahat Gorduysus
Department of Endodontics, Hacettepe University, Turkey

Correspondence: Omer Gorduysus M, Hacettepe University, Faculty of Dentistry, Department of Endodontics, Hacettepe University, Universiteler Mh., 06640 Ankara,Turkey, Tel 90532 2556518,Email ogorduysus@yahoo.com

Received: June II, 20I4 | Published: July 26, 20 I4

Keywords: cytotoxicity, ${ }^{51} \mathrm{Cr}$-release, resin, AH26, AH plus

\section{Introduction}

The biocompatibility of a root canal sealer plays a significant role in the success of endodontic treatment. ${ }^{1}$ The components of these materials can act as general toxins or as specific toxins which target certain metabolic pathways. In both instances, cellular injury can lead to tissue damage or delay and impede tissue repair.

Several in vitro methods have been recommended for the evaluation of cytotoxicity of endodontic materials. ${ }^{2}$ The American National Standards Institute, the American Dental Association, the Technical Report ISO-TR 7405 of the International Standards Organization Committee concerned with dentistry (TC 106) and FDI have published guidelines for material evaluation that encourage the use of in vitro methods. ${ }^{3-5}$

The radiochromium $\left({ }^{51} \mathrm{Cr}\right)$ release method was introduced by Spangberg. ${ }^{6}$ According to the method, cells are labeled with ${ }^{51} \mathrm{Cr}$ in the form of sodium chromate, which binds with the intracellular proteins. Toxicity results in cellular changes and the release of the radioactive chromium, which is proportional to the cytotoxic effect of the particular material.

A variety of root canal sealers are currently available and include zinc oxide-eugenol, calcium hydroxide and epoxy resin-based formulations. More recently, a new epoxy resin-based material, $\mathrm{AH}$ Plus, has been introduced. AH Plus has been claimed to be an improved paste to paste material based on epoxy amine resins. ${ }^{7}$ Because of its non-formaldehyde releasing formulation, AH Plus has a less cytotoxic effect than AH26. Compared with studies carried out on $\mathrm{AH} 26$, there have been a limited number of studies investigating the cytotoxicity of AH Plus. ${ }^{8}$ The purpose of the present study was to compare the cytotoxicity of these two epoxy resin-based root canal sealers using the ${ }^{51} \mathrm{Cr}$ release method.

\section{Materials and methods}

The study used $16 \times 10^{6}$ heteroploid L929 mouse fibroblasts in 40ml Eagles' MEM (minimum essential medium) which contained $10 \%$ fetal bovine serum (FBS; HyClone, Logan, Utah), 10.000 units of penicillin-G/ml, 10mg of Streptomycin $/ \mathrm{ml}$, and $200 \mathrm{mM}$ of L-glutamine (Sigma Chemical Co., St Louis). Cells were maintained at $37^{\circ} \mathrm{C}$ under $5 \% \mathrm{CO}_{2}, 100 \%$ humidity, and were labeled with $300 \mu \mathrm{Ci}{ }^{51} \mathrm{Cr}$ in the form of isotonic sodium chromate solution for $24 \mathrm{~h}$. The labeled cells were rinsed three times with phosphate buffer solution (PBS) to eliminate unbinded ${ }^{51} \mathrm{Cr}$ remnants. The rinsed cells were diluted with PBS as $4 \times 10^{5}$ cells in one milliliter. Subsequently, $0.5 \mathrm{mg}$ of fresh mixture of each endodontic test material, AH26 (DeTrey, Dentsply, Germany) and AH Plus (DeTrey, Dentsply) were placed into five different test tubes for $12 \mathrm{~h}$ and five test tubes for $72 \mathrm{~h}$. In total, twenty test tubes were prepared with samples weighted under aseptic conditions according to the manufacturers' directions.

One positive and one negative control were prepared for each test tube. Labeled, but material free cell suspension was used as negative control and labeled cell suspension that contains $0.5 \mathrm{ml}$ formocresol (Sultan Co. UK) was used as positive control group.

All the test sample tubes were placed on a homogenisator, and later $1 \mathrm{ml}$ of cell culture suspension from each test sample tube was centrifuged at $500 \mathrm{xg}$ for 8 minutes, thereafter $0.5 \mathrm{ml}$ of supernatants were counted with gamma particle counter (Wallac 1480 Wizard 3 Gamma Counter). Overall differences among the groups in ${ }^{51} \mathrm{Cr}$ release at $12 \mathrm{~h}$ and $72 \mathrm{~h}$ were evaluated using the Kruskal-Wallis test. The Wilcoxon Sum-Rank test was applied to assess significant pairwise comparisons in ${ }^{51} \mathrm{Cr}$ release between each test material and the control groups. Differences within test groups, between 12 and 72 hour readings, were evaluated using the Wilcoxon Signed-Rank test.

\section{Results}

The results at 12 and 72 hours are presented in Table 1 and 2, respectively, and in Figure 1. Overall differences were noted in gamma particle readings for the sealer and control groups at $12 \mathrm{~h}$ and $72 \mathrm{~h}$ (Kruskal-Wallis Test, p=0.001). AH26 and AH Plus had comparable results which were significantly lower than those of the positive control and significantly higher than those of the negative control samples (Wilcoxon Sum-Rank test, $\mathrm{p}<0.05$ ). There was not any significant difference between AH26 and AH Plus at $12(\mathrm{p}=0.834)$ and $72 \mathrm{~h}(\mathrm{p}=0.676)$. There was a borderline significant increase in ${ }^{51} \mathrm{Cr}$ release from 12 to 72 hours for both AH26 and AH plus (Wilcoxon Signed-Rank test, $\mathrm{p}=0.062$ ). 
Table I Gamma counter readings at $12 \mathrm{~h}$.

\begin{tabular}{|c|c|c|c|c|c|c|c|}
\hline & \multicolumn{7}{|c|}{ TEST SAMPLES } \\
\hline & $\mathbf{I}$ & 2 & 3 & 4 & 5 & Mean & SD \\
\hline \multicolumn{8}{|c|}{ ROOT CANAL SEALERS } \\
\hline $\mathrm{AH} 26$ & 336.5 & 378.6 & 362.2 & 341.7 & 381.2 & 360.0 & 20.54 \\
\hline $\mathrm{AH}$ Plus & 360.1 & 339.7 & 384.1 & 337.9 & 344.6 & 353.3 & 19.32 \\
\hline (-) Control & 122.1 & 117.7 & 120.8 & 115.0 & 123.3 & 119.8 & 3.38 \\
\hline (+) Control & 653.7 & 789.7 & 620.2 & 641.3 & 780.4 & 697.1 & 81.28 \\
\hline
\end{tabular}

SD: Standard Deviation; (-) Control: Labeled but Material Free Cells; (+) Control: Formocresol

Table 2 Gamma counter readings at $72 \mathrm{~h}$.

\begin{tabular}{llllllll}
\hline & \multicolumn{9}{c}{ TEST SAMPLES } & & & & \\
& $\mathbf{I}$ & $\mathbf{2}$ & $\mathbf{3}$ & $\mathbf{4}$ & $\mathbf{5}$ & Mean & SD \\
\hline ROOT CANAL SEALERS & & & & & & & \\
AH26 & 684.0 & 660.0 & 671.0 & 679.3 & 663.3 & 671.5 & 10.21 \\
AH Plus & 666.2 & 677.1 & 682.0 & 661.0 & 659.0 & 669.1 & 10.08 \\
(-) Control & 487.5 & 501.1 & 492.0 & 472.2 & 483.0 & 487.2 & 10.71 \\
$(+)$ Control & 1330.4 & 997.8 & 1271.1 & 981.0 & 1172.0 & 1150.5 & 157.65 \\
\hline
\end{tabular}

SD, standard deviation; (-) Control, labeled but material free cells; (+) Control, Formocresol

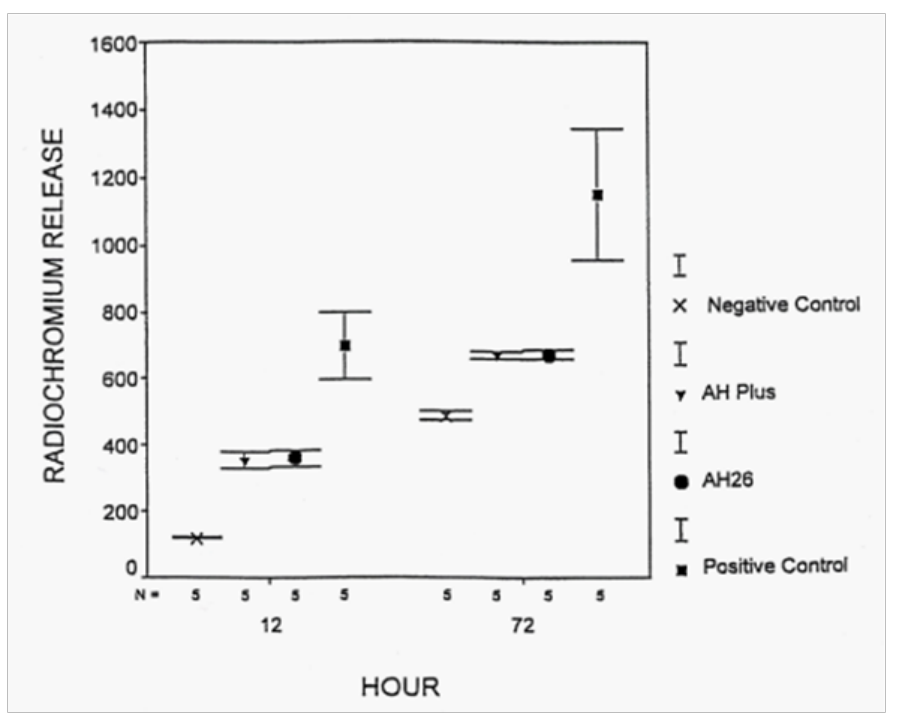

Figure I Cytototoxicity (mean $5 \mathrm{ICr}$ scores and $95 \%$ confidence intervals) of $\mathrm{AH}$ plus and $\mathrm{AH} 26$ at 12 and 72 hours.

\section{Discussion}

There is not enough information available on the cytotoxic effect of $\mathrm{AH}$ plus. The ${ }^{51} \mathrm{Cr}$ assay is extremely sensitive and has a good dose-effect relationship for most toxic agents, ${ }^{9}$ while the level of radiation used during this type of experiment is low. ${ }^{10}$ The results of in vitro and in vivo studies often do not correlate but the cytotoxic induction of any test material in the cell culture medium can be regarded as similar to the living tissues.

Briseno and Willerhausen ${ }^{11}$ concluded that AH26 showed severe cytotoxic reaction after 24 hours in comparison to Diaket and Endo-
Fill. The same conclusion has been supported by other studies. ${ }^{12-15}$ It is possible that $\mathrm{AH} 26$ releases formaldehyde during the setting reaction which is responsible for the toxicity of AH26. Similar to our results, Jukic et al. ${ }^{16}$ evaluated that both, $\mathrm{AH} 26$ and $\mathrm{AH}$ plus were cytotoxic and that $\mathrm{AH}$ plus was more toxic than $\mathrm{AH} 26$.

Based on the chromium release method and procedure used in the present study, AH26 and AH Plus have the same degree of cytotoxic effect at 12 and $72 \mathrm{~h}$. The adequate combination of sealing ability and biocompatibility of a root canal sealer is important for a favorable prognosis in root canal treatment. Since in vitro toxicity studies are scarce and the dynamic nature of human periapical tissues cannot easily be simulated in vitro, further studies are needed to evaluate the toxicity of sealing materials in endodontics.

\section{Acknowledgments}

None.

\section{Conflict of interest}

The author declares that there is no conflict of interest.

\section{References}

1. Barbosa SV, Araki K, Sparigberg LS. Cytotoxicity of some modified root canal sealers and their leachable components. Oral Surg Oral Med Oral Pathol. 1993;75(3):357-361.

2. Browne RM. The in vitro assessment of the cytotoxicity of dental materials-does it have a role? Int Endod J. 1988;21(2):50-58.

3. Osorio RM, Hefti A, Vertucci FJ, et al. Cytotoxicity of Endodontic Materials. J Endodon. 1998;24(2):91-96.

4. ANSI/ADA. ANSI/ADA American National Standards Institute/ American Dental Association, Specification No. 41 in biological evaluation of dental materials. 1979. 
5. FDI. FDI Recommended standard practices for biological evaluation of dental materials. Technical Report no 9. Int Endod J. 1980;30(2):140-188.

6. Spangberg L. Kinetic and quantitative evaluation of material cytotoxicity in vitro. Oral Surg Oral Med Oral Pathol. 1973;35(3):389-401.

7. Zmener O, Spielberg C, Lamberghini F, et al. Sealing properties of a new epoxy resin-based root-canal sealer. Int Endod J. 1997;30(5):332-334.

8. Gutmann JL, Witherspoon DE. Obturation of the cleaned and shaped root canal system. In: Cohen S, Burns RC, editors. Pathways of the Pulp. 7th ed. Mosby Co, St Louis, USA;1988:269.

9. Hensten-Pettersen. A Comparison of the methods available for assessing cytotoxicity. Int Endod J. 1998;21(2):89-99.

10. Spangberg LSW, AI-Nazhan SA. The radiochromium release method for evaluation of cytotoxicity in vitro. Int Endod J. 1998;21(2):72-78.

11. Briseno BM, Willerhausen B. Root canal sealer cytotoxicity on human gingival fibroblasts: 2. silicone and resin-based sealers. J Endodon. 1991;17(11):537-540.
12. Hensten-Pettersen A, Brstavik D, Wennberg A. Allergic potential of root canal sealers. Endod Dent Traumatol. 1985;1(2):61-65.

13. Nakamura H, Sakakibara F, Matsumoto Y. Study on the cytotoxicity of root canal filling materials. J Endod. 1986;12(4):156-160.

14. Spangberg L, Pascon EA. The importance of material preparation for the expression of cytotoxicity during in vitro evaluation of biomaterials. $J$ Endod. 1988;14(5):247-250.

15. Olsson B, Wennberg A. Early tissue reaction to endodontic filling materials. Endod Dent Traumatol. 1985;1(4):138-141.

16. Miletic I, Jukic S, Anic I, et al. Evaluation of the cytotoxicity of AH+ and AH26 on Chinese Hamster V79 cells. Int Endod J. 2000;34(3):143. 